\title{
標準家系に扔いて交配様式括よびマーカーの多型数と その頻度が連鎖解析の効率に及ぼす影響
}

\author{
佐藤正寛・古川 力 \\ 農林水産省畜産試験場，茨城県筑波農林研究団地 305-0901
}

(1998. 11. 25 受付)

\begin{abstract}
要 約 標準家系に捛いて交配様式扔よびマーカーの多型数と型の頻度（以下，遺伝子頻度）が連鎖 解析の効率に及ぼす影響をモンテカルロ法によるコンピュータシミュレーションによって調べた．標準 家系は二重相互交配または戻し交配によって作成するすのとした，まず，雄家系加ら雄 3 頭，雌家系か

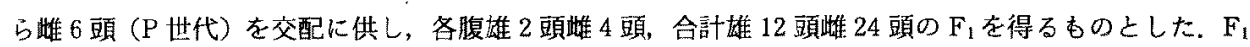
同士の無作為交配（二重相互交配），または $\mathrm{F}_{1} の$ 雄または雌のいずれかを雄家系または踓家系に無作為 に戻し交配し，各䧗 8 頭の子を産するものとした。まず，すべてのマーカーの多型数を 2 とし，家系の 棈造とマーカーの遺伝子頻度が連鎖解析の効率に及代す影響について調べた。次に， $\mathrm{P}_{1}$ および $\mathrm{P}_{2}$ のマー カーの多型数をそれぞれ 2 10 とし，マーカーの多型数ならびにその遺伝子頻度の影響を調べた，最後 に，マーカー間の距離のばらつきが連銷解析の効率に及ぼす影響について調べた. 染色体の長さは 1.2 $\mathrm{M}$ (モルガン)，マーカーの平均間陑は $0.05,0.10,0.15$ または $0.20 \mathrm{M}$ とした。 マーカー間の推定距離の 平均二乗譔差㧠よびロッドスコアを連鎖解析の効率の指標とした，その結果，二重相互交配は戻し交配 よりも連鎖解析の効率は高い傾向にあった。ママーカーの多型数が多いほじ連鎖解析の效率は高まる傾向 にあったが，多型数を極端に多くしても，連鎖解析の効率の上昇率は小さいものであった。 マーカ一間 の距離のばらっきは連鱝解析の効率に大きな影響を及ぼすものではなかった。
\end{abstract}

日畜会報, $69(5): 460-468,1998$

既知の遗伝子やDNA マーカー（以下，マーカー）に よって主働倳伝子等の位置を同定するための方法とし て，迶伝連銷地図の利用がある，精密な遺伝連鎖地図を 作成するためには，まずマ一カ一間の連鎖解析を効率的 にすすめる必要がある゙13．家畜等では，連鎖地図を効率 的に作製するとともに主動道伝子をはじめとする QTL （量的形質関連倦伝子群）の位置を同定するための1つ の手法として，標準家系 (reference family) を作成し， こ机に基づいた連銷解析が行われているる の効率は様々な要因によって影響を受けておりり年, 6,8)，効 率的な連銷解析老行うための研究がなされている, が、これらは標染家系を前提としたものではない，慓準 家系に基づく連銷解析では実験的に家系を作成するた め，労力やコストの面から屯より効率的な実験計画が望 まれる。この上うな見地から，標準家系における効率的 な連鎖解析の実験計画法について検討されてきた ${ }^{10-12)}$.

本研究は二重相互交配または戻し交配加らなる柾準家
系を想定し，マーカーの多型数およびその型（以下，対 立遗伝子とする，ただし，マーカーは遺伝子である必要 はない）の頻度が運鎖解析の効率に及に゙す影響をコン ピュータシミュレーションによって明らかにすることを 目的とした。

\section{方法}

マーカーの多型数および対立遺伝子の頻度（以下，遺 伝子頻度とする）が連鎖解析の効率に及ぼす影響を明ら かにするため，異なる2つの集団の二重相互交配または 戻し交配に上る標準家系を想定し，標準家系の各個体の マーカーの対立遗伝子をモンテカル口法によるコン ピュータシミュレーションにより発生させた。標準家系 の基礎となる 2 品種（P世代）の一方を雄家系 $\left(\mathrm{P}_{1}\right)$ ，他 方を䊒家系 $\left(\mathrm{P}_{2}\right)$ 亡する。 $\mathrm{P}_{1}$ 加ら雄 3 頭， $\mathrm{P}_{2}$ 加 ら雌 6 頭 を交配し, 各腹滩 2 頭雌 4 頭, 合計雄 12 頭雌 24 頭の $F_{1}$ を得る屯のとした，二重相互交配の場合は $\mathrm{F}_{1}$ 同士を無 
作為に，戻し交配の場合は $\mathrm{F}_{1}$ の雄老雄家系の雌または

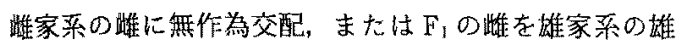
または睢家系の雄に無作為交配する4通りを想定し，い ずれの交配においても膗は各腹 8 頭の子を座するもの上 した.

いま， $\mathrm{i}$ 番目のマーカー $\mathrm{M}_{\mathrm{i}} \sigma \mathrm{j}$ 番目の対立頲伝子の頻 度を $q_{i j}$ とする. まずすべてのマーカーの多型数を 2 と し，二重相互交配㧍よび戻し交配（家系の構造）とマカーの遺伝子頻度が連鎖解析の効率に及ぼす影響につい

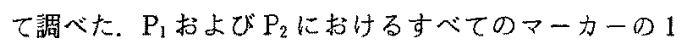
番目の対立遗伝子の頻度 $\mathrm{q}_{i 1}$ の組み合わせを $\left(\mathrm{P}_{1}\right.$ ○ $\mathrm{q}_{\mathrm{il}}$, $\left.\mathrm{P}_{2} の \mathrm{q}_{\mathrm{i1}}\right)=(0.1,0.1),(0.3,0.3),(0.5,0.5),(0.1,0.9)$ お よひ $(0.3,0.7)$ とした. また, これらの対照として, $P_{1}$ および $\mathrm{P}_{2}$ の各マーカーの対立遗伝子の頻度を無作為に 発生させたすのを用いた。マーカーは等間隔に配置され るすの上した。

次に， $\mathrm{P}_{1}$ 执よび $\mathrm{P}_{2}$ のマーカーの多型数 (NP) 在をれ ぞれ2〜10とし，マーカー $\mathrm{M}_{\mathrm{i}}$ の多型数 $\left(\mathrm{NP}_{\mathrm{i}}\right)$ 々その対 立遺伝子の頻度 $\mathrm{q}_{\mathrm{ij}}$ を, (1) $N P_{\mathrm{i}}=N P, \mathrm{q}_{\mathrm{ij}}=1 / N \mathrm{NP}_{\mathrm{i}}$ （2) $N \mathrm{NP}_{\mathrm{i}}=$ $\mathrm{NP}, \mathrm{q}_{\mathrm{ij}}=$ 然作為発生, (3) NP $\mathrm{i}=2 \sim N P$ の籍国で哭作為発 生, $\mathrm{q}_{\mathrm{ij}}=1 / \mathrm{NP}_{\mathrm{i}}$, (4) $\mathrm{NP}_{\mathrm{i}}=2 \sim \mathrm{NP}$ の範囲で無作為発生, $\mathrm{q}_{\mathrm{ij}}$ 二烈作為発生，とする4 通りのケースについて調べた。 標集家系は二重相互交配とし，マーカーは等間隔に配置 されるるのとした。

最後に，遺伝子頻度よマーカー間の距離のばらつきと の関係を調べた。 まず，すべてのマーカーの多型数を 2

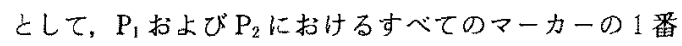
目の対立遗伝子の頻度 $\mathrm{q}_{\mathrm{i} 1}$ の組两合わせを( $\mathrm{P}_{1}$ の $\mathrm{q}_{\mathrm{i}}, \mathrm{P}_{2}$ $\left.\sigma \mathrm{q}_{\mathrm{if}}\right)=(0.3,0.7) ，(0.4,0.6),(0.5,0.5),(0.4,0.4)$ 扎よ む゙ $(0.3,0.3)$ とした. 次に, マーカーの多型数はすべての マーカーで等しいものとし，多型数とマーカ一間の距離

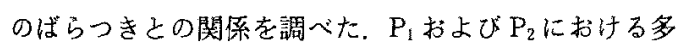
型数はをれぞれ 2〜4のいずれかを仮定し，それらの遣 伝子頻度はすべて（1/多型数）とした，いずれの場合に おいても，標準家系は二重相互交配加らなる向のとし，

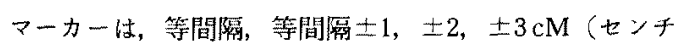
モルガン) 標準偏差として、マ一カ一の間隔にばらつき を与旮た。

マーカーはすべて共優性を示す多型がみられ，2個の マーカ一は染色体上の両端に位置するすのとした，染色 体の長さは1.2 M(モルガン)，マーカ一の平均間隔は $0.05,0.10 ， 0.15 ， 0.20 \mathrm{M} の 4$ 通りを想定した。 それぞれ の条件下において，マ一カーが染色体上に等間隔にある 場合には 1,000 反復のデータを，またマ一カ一の間隔が 不等間滆の場台にはそのような家系を20家系発生させ，
各家系内で 50 反復のデータをコンピュータにより発生 させた．コンピュータシミュレーションにより発生させ たマーカーを調べることにより，マーカー間の推定距離 の平均二乗䛊差の平方根 (SMSE) を算出するとと屯に, マーカー間の平均ロッドスコア (Z值 $)^{7)}$ 算出した.こ こで, SMSE は遭伝連鎖地図を作製するためのマーカー 䦭の推定距離の正確さを示す指標であり，また乙値沬 マーカ一間の連鎖の程度を示す指標である。なお は，世代 P の遺伝子型を調心゙, $F_{1}$ 世代の相が判明する場 合には 3 世代の家系情報による連鎖解析から，F 相が判明しない場合には2 世代の家系情報による連鎖解 析から算出した。

結 果

多型数が 2 の場合に扔けるマーカーの遗伝子頻度上交 配様式が連鎖解析の効率に与える影響を表 1 お よび表 2 に示した，表1はマーカー間のSMSEを，表 2 は值を 示している，ただし，戻し交配で $F_{1}$ の雄を雄家系の崔お

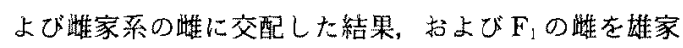

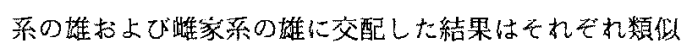
していたので，表にはそれぞれの平均を示した，雄家系 まよび柴家系の 1 番目の対立遺伝子の頻度がと屯に 0.3

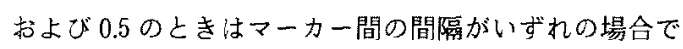
あ，戻し交配のSMSE は二重相互交配のそれより手小 さくなったが，それ以外の場合には二重相互交配の SMSE は戻し交配のそれよりも小さくなった，雄家系お 上び崔家系の1番目の対立遗伝子の頻度が之もに0.1の

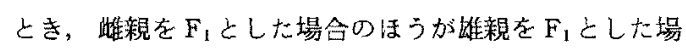
合よりあSMSEは小さくなった。この傾向は连伝子頻 度を無作為に発生させた場合にもみられたもののその差 は小さく，それ以外の場合に両者の間に大きな差はみら れなかった，SMSEが小さくなる組み合わせでは平均 Z 值は大きく，逆にSMSEが大きくなる組み合わせでは 平均Z值は小さくなる傾向が認めら扎た。

図 1 に, $N P_{i}=N P, q_{i j}=1 / N P_{i}$ とした場合（ケース1: 図 $1 a), N P_{i}=N P, q_{i j}=$ 無作為発生とした場合（ケース 2 : 図 $1 \mathrm{~b}), N P_{i}=2 \sim \mathrm{NP}$ の筙四で無作為発生, $\mathrm{q}_{\mathrm{ij}}=1 / \mathrm{NP}_{\mathrm{i}}$ しした場合（ケース 3:図 1c），执上び $\mathrm{NP}_{\mathrm{i}}=2 \sim \mathrm{NP}$ の 箐囲で無作為発生, $\mathrm{q}_{\mathrm{ij}}$ 二無作為発生とした場合（ケース 4: 図1d）のSMSE 示した。ケース1では，P世代の 一方の家系のマーカーの多型数が多い場合（5以上）に は，他方の家系のマーカーの多型数はSMSEにはとん ど影響しなかった。ケース3では，多型数が多いはよ゙ SMSE は小さくなる傾向がみられた。ケース2および ケース4の SMSEは，それぞれケース 1 执よびケース 3 
佐藤・古川

Table 1. Square root of mean square error of average length between markers with different frequencies of marker allele in different structure of reference population

\begin{tabular}{|c|c|c|c|c|c|c|c|}
\hline \multicolumn{2}{|c|}{ Gene frequency } & \multicolumn{2}{|c|}{ Structure } & \multicolumn{4}{|c|}{ Interval between markers $(\mathrm{M})$} \\
\hline Sire line & Dam line & Sire & Dam & 0.05 & 0.10 & 0.15 & 0.20 \\
\hline \multirow[t]{3}{*}{0.1} & 0.1 & $F_{1}$ & $F_{1}$ & 0.049 & 0.075 & 0.089 & 0.098 \\
\hline & & $F_{1}$ & $\mathrm{P}$ & 0.063 & 0.094 & 0.108 & 0.116 \\
\hline & & $\mathrm{P}$ & $F_{1}$ & 0.050 & 0.080 & 0.093 & 0.104 \\
\hline \multirow[t]{3}{*}{0.3} & 0.3 & $F_{1}$ & $F_{1}$ & 0.033 & 0.051 & 0.060 & 0.065 \\
\hline & & $F_{1}$ & $P$ & 0.030 & 0.044 & 0.054 & 0.062 \\
\hline & & $\mathrm{P}$ & $\mathrm{F}_{1}$ & 0.030 & 0.045 & 0.056 & 0.062 \\
\hline \multirow[t]{3}{*}{0.5} & 0.5 & $F_{1}$ & $F_{1}$ & 0.026 & 0.038 & 0.046 & 0.052 \\
\hline & & $F_{i}$ & $\mathrm{P}$ & 0.024 & 0.036 & 0.043 & 0.049 \\
\hline & & $\mathrm{p}$ & $F_{1}$ & 0.024 & 0.036 & 0.043 & 0.050 \\
\hline \multirow[t]{3}{*}{0.3} & 0.7 & $F_{1}$ & $F_{1}$ & 0.023 & 0.034 & 0.042 & 0.047 \\
\hline & & $F_{1}$ & $P$ & 0.024 & 0.036 & 0.043 & 0.049 \\
\hline & & $P$ & $F_{1}$ & 0.025 & 0.036 & 0.043 & 0.049 \\
\hline \multirow[t]{3}{*}{0.1} & 0.9 & $F_{1}$ & $F_{1}$ & 0.016 & 0.023 & 0.029 & 0.033 \\
\hline & & $\mathrm{F}_{1}$ & $\mathrm{P}$ & 0.020 & 0.028 & 0.034 & 0.038 \\
\hline & & $\mathrm{P}$ & $F_{1}$ & 0.020 & 0.028 & 0.034 & 0.038 \\
\hline \multirow[t]{3}{*}{ Random } & Random & $F_{1}$ & $F_{1}$ & 0.031 & 0.046 & 0.054 & 0.063 \\
\hline & & $F_{1}$ & $\mathrm{P}$ & 0.036 & 0.050 & 0.059 & 0.066 \\
\hline & & $\mathrm{P}$ & $F_{1}$ & 0.032 & 0.049 & 0.056 & 0.065 \\
\hline
\end{tabular}

Table 2. Mean lod score between markers with different frequencies of marker allele in different structure of reference population

\begin{tabular}{|c|c|c|c|c|c|c|c|}
\hline \multicolumn{2}{|c|}{ Gene frequency } & \multicolumn{2}{|c|}{ Structure } & \multicolumn{4}{|c|}{ Interval between markers $(M)$} \\
\hline Sire line & Dam line & Sire & Dam & 0.05 & 0.10 & 0.15 & 0.20 \\
\hline \multirow[t]{3}{*}{0.1} & 0.1 & $\mathrm{~F}_{1}$ & $F_{1}$ & 5.60 & 4. 26 & 3. 22 & 2.31 \\
\hline & & $F_{1}$ & $P$ & 3. 83 & 2.89 & 2. 13 & 1.62 \\
\hline & & $\mathrm{P}$ & $F_{1}$ & 4. 39 & 3.32 & 2. 5.1 & 1.84 \\
\hline \multirow[t]{3}{*}{0.3} & 0.3 & $\mathrm{~F}_{1}$ & $\mathrm{~F}_{1}$ & 11.95 & 8.75 & 6.52 & 4.75 \\
\hline & & $F_{1}$ & $\mathrm{P}$ & 11.81 & 8.64 & 6.34 & 4.46 \\
\hline & & $\mathrm{P}$ & $F_{1}$ & 11.80 & 8.75 & 6.24 & 4. 39 \\
\hline \multirow[t]{3}{*}{0.5} & 0.5 & $F_{1}$ & $F_{1}$ & 16.01 & 11.63 & 8.61 & 6.12 \\
\hline & & $F_{1}$ & $\mathrm{P}$ & 16.02 & 11.64 & 8. 25 & 5.83 \\
\hline & & $\mathrm{P}$ & $F_{1}$ & 16.03 & 11.54 & 8. 40 & 5.84 \\
\hline \multirow[t]{3}{*}{0.3} & 0.7 & $\mathrm{~F}_{1}$ & $F_{1}$ & 18. 64 & 13. 68 & 9.73 & 6.95 \\
\hline & & $F_{1}$ & $\mathrm{P}$ & 16.92 & 12.40 & 8. 98 & 6.29 \\
\hline & & $P$ & $F_{1}$ & 16.94 & 12. 41 & 9.01 & 6.39 \\
\hline \multirow[t]{3}{*}{0.1} & 0.9 & $F_{1}$ & $F_{1}$ & 30.53 & 20.95 & 14. 42 & 9.59 \\
\hline & & $F_{1}$ & $\mathrm{P}$ & 26.60 & 19.81 & 14.51 & 10.37 \\
\hline & & $\mathrm{P}$ & $F_{1}$ & 26.60 & 19.78 & 14. 58 & 10.40 \\
\hline \multirow[t]{3}{*}{ Random } & Random & $\mathrm{F}_{1}$ & $F_{1}$ & 14.40 & 10.78 & 7.74 & 5.11 \\
\hline & & $F_{1}$ & $\mathrm{P}$ & 12.66 & 9.64 & 6.97 & 4.80 \\
\hline & & $\mathrm{P}$ & $F_{1}$ & 12.73 & 9.63 & 6. 97 & 4.73 \\
\hline
\end{tabular}



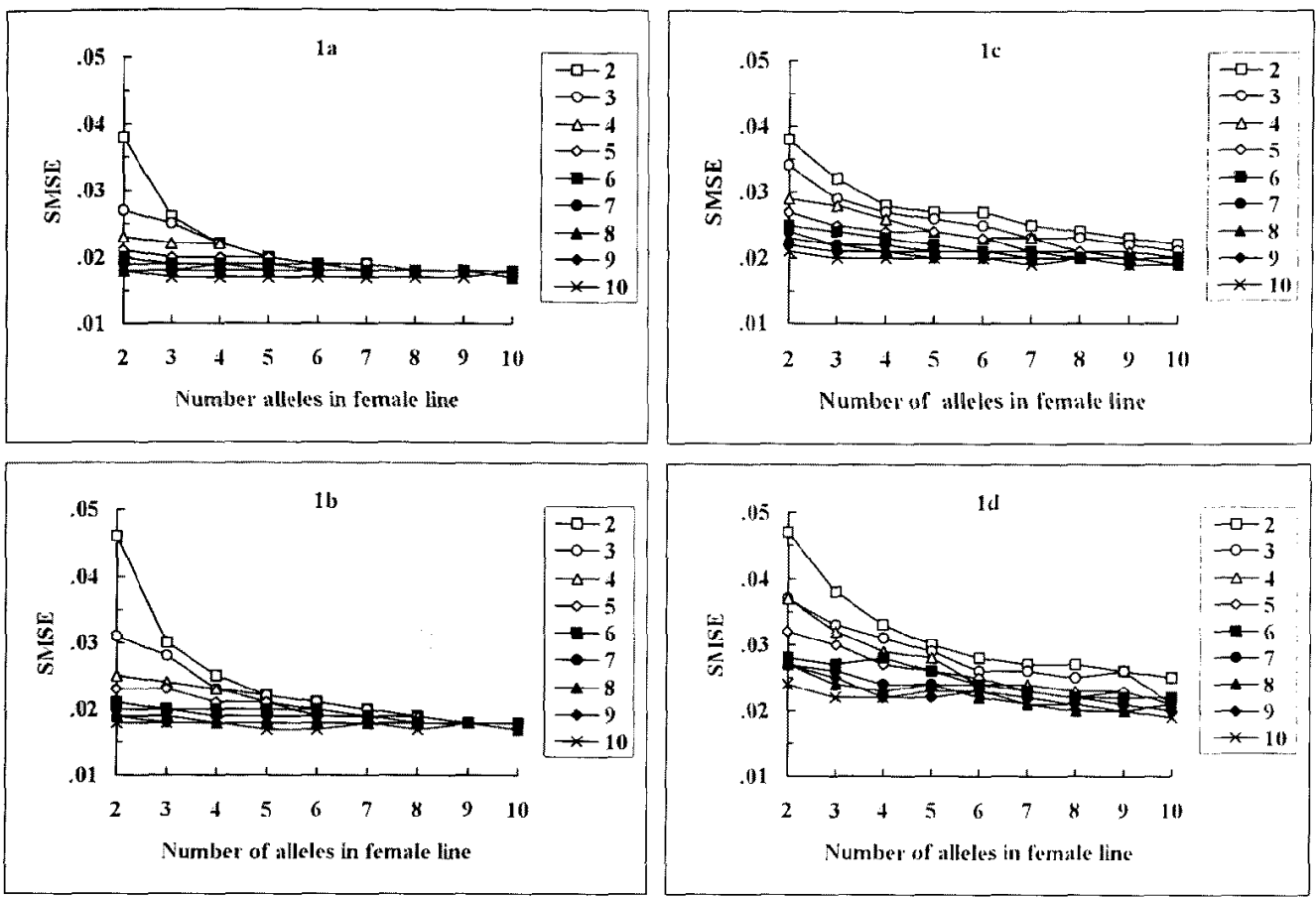

Fig. 1. Square root of mean square error of average length (SMSE) between markers with different number of alleles [Fig. $1 \mathrm{a}: \mathrm{NP}_{\mathrm{i}}$ (number of polymorphism of $i^{\text {th }}$ marker) $=\mathrm{NP}, \mathrm{q}_{\mathrm{ij}}$ (frequency of $j^{\text {th }}$ allele of $i^{\text {th }}$ marker) $=1 / N P_{i} ;$ Fig. $1 \mathrm{~b}: N P_{i}=N P, q_{i j}=$ random frequency); Fig. $1 \mathrm{c}$ : $N_{i}=$ random number between 2 and $N P, q_{i j}=1 / N P_{i} ; F i g, 1 d: N P_{i}=$ random number between 2 and $N P, q_{i j}=$ random frequency]. Figures in the legends indicate number of alleles in male line.

のそれよりあ大きくなり，多型数が少ないほどその㑯向 は強かった、いずれのケースで多型数が多くなるにし たがい，SMSEの娍少率は低くなる傾向にあった。 ケ一 ス1〜4のZ值を図2に示した（をれぞれ图 2a〜d）. ケース1およびケース 2 では，Z值は多型数の多い家系 に依存した值をとる傾向にあった。 ケース 1，ケース 2 抬よびケース3では，一力の家系の多型数を一定にした 場合，他方の家系の多型数が增すにつれて Z 值は增加し たが，その增加率は滅少した。この傾问は，特にケース 1およびケース2において顕著であった。なお、雌家系 の多型数を 2 から 3 に増加させたとき，図 $1 \mathrm{~d} の \mathrm{SMSE}$ は城少し, 図2dのZ值は増加しているが,これは SMSEとZ值との関係が比例関係にあるとは限らない ためである。

多型数が 2 の場合におけるマーカ一の遺伝子頻度亡 マ一カ一間の距離のばらつきとの関係を表 3 に示した。

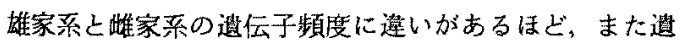

伝子頻度が等しい場合にはそれが 0.5 に近いほぼ速鎖解 析の效率は高ま吕傾向にあった。マーカーの平均間隔が $0.05 \mathrm{M}$ のときに、、ーカー間の距離のばらつきの程度 が大きいほど, SMSEは鏵かに大きくなる傾向を示し た.しかし、マーカー間の距離のばらつきは $Z$ 值にはほ とんど影響を及ぼさなかった。多型数を変えた場合の マーカーの遗伝子頻度とマーカー間の距離のばらつきと の関係を表 4 に示した，図1の場合と同樣，各家系の多 型数が多いはよ゙連銧解析の效率は高まる倾向にあった が、マーカー間の距離のばらつきはSMSEやZ譪に影 留者与えなかった。

\section{考察}

マーカーの多型数が 2 の場合，特に二重相互交配では 婎家系と睢家系の遗伝子頻度に違いがあるほど連銷解析 の効率は高まる傾向がみられた。この理由はF $\mathrm{F}_{1}$ 世代の 二重へテロの制合が高まるためし考えられる。事実，雄 
佐藤・古川
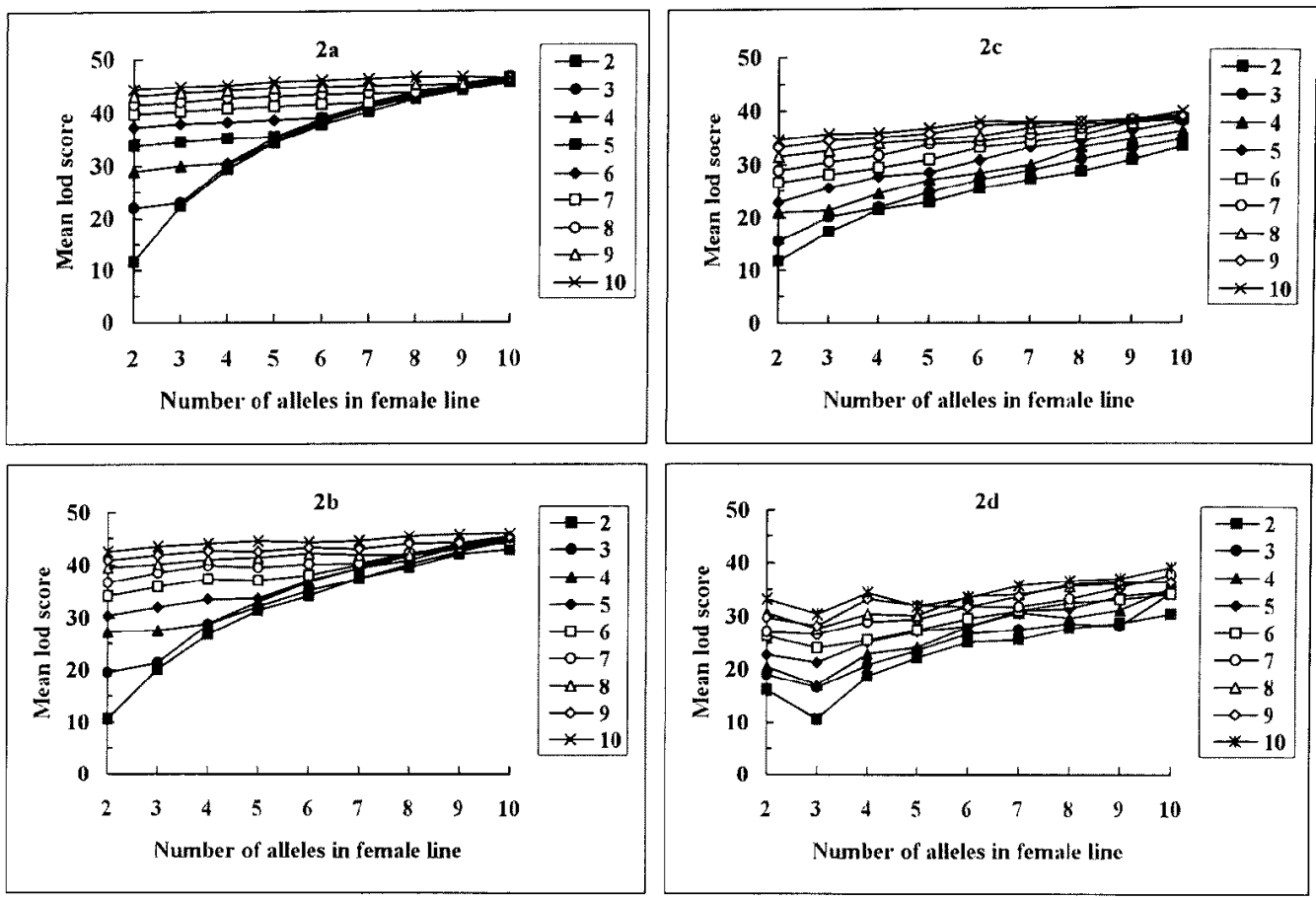

Fig. 2. Mean lod score between markers with different number of alleles. [Fig. 2a:NP (number of polymorphism of $i^{\text {th }}$ marker) $=N P, q_{i j}$ (frequency of $j^{\text {th }}$ allele of $i^{\text {th }}$ marker) $=1 / N P_{i}$; Fig. $2 \mathrm{~b}: \mathrm{NP}_{\mathrm{i}}-\mathrm{NP}, \mathrm{q}_{\mathrm{ij}}=$ random frequency); Fig. $2 \mathrm{c}: \mathrm{NP}_{\mathrm{i}}=$ random number between 2 and $\mathrm{NP}, \mathrm{q}_{\mathrm{ij}}$ $=1 / \mathrm{NP}_{\mathrm{i}} ; \mathrm{Fig} .2 \mathrm{~d}: \mathrm{NP}_{\mathrm{i}}=$ random number between 2 and $\mathrm{NP}, \mathrm{q}_{\mathrm{ij}}=$ random frequency]. Figures in the legends indicate number of alleles in male line.

家系および继家系の 1 番目の対立遺伝子の頻度がそれ ぞれ $0.1 ， 0.9$ の上き，二重相互交配における $\mathrm{F}_{1}$ 世代の二 重へテロの割合は全体の約 $87 \%$ であったのに対して, 遺伝子頻度がともに 0.5 のときは約 $43 \%$ にすぎなかっ た.

表には示していないが，雄家系および䧳家系の1番目 の対立遇伝子の頻度がともに 0.5 のとき， $F_{1}$ 世代の二重 へテロの割合は，二重相互交配およで戻し交配ではほと んど差がみられなかったのに対し，遭伝子頻度がそれ ぞれの家系で 0.1，0.9 のときは，二重相互交配は戻し交 配に比べて約 9\%大きかった，連銷解析では，解析した い2 個のマーカーのうちのいずれか一方が少なく上も二 重へテロである必要がある。しかし，両親のマーカーの 相（phase）が末知の場合あるいは片親だけが既知の場 合には，Z值は二重へテロ同士の交配よりも二重へテロ と二重示モの交配のほうが高くなる。家系間に遭伝子頻 度の暹いがみられる場合, 戻し交配は二重相互交配に比
ベて, $\mathrm{F}_{1}$ 世代の二重へテロの割合は小さくなるものの, その分二重亦モの割合が高くなると考えられる。このよ うな理由加ら，二重相互交配は戻し交配に比一，連銷解 析の効率は高くなる傾向がみられたが，その善は小さい あのであったと推察される.

ケース 1 およびケース 2 は, 染色体上のすべてのマー カーの NP が各家系内で同一であると仮定したもので ある. 一方, ケース 3 およびケース 4 は，マーカーごと に $\mathrm{NP}_{\mathrm{i}}$ が異なり，マーカーの $\mathrm{NP}_{\mathrm{i}}$ の分布は $2 \sim \mathrm{NP}$ の範 囲内で一様であると仮定したものである，予想されたと おり，マ一カーの多型数が多いほざ連銷解析の効率は高 まったししかしそそれが 5 以上になってあ連鎖解析の効 率に著しい改善効果はみられなかった。このことは，特 にケース 3 およびケース 4 において顕著であった。した がって，多型数が 5 以上であれば，マーカーの選定には 多型数より香それらの染色体上の位置関係や電気永動パ ターンの難易等を考慮することが望ましいといえる。 


$$
\text { マーカーの多型数と連敛解析 }
$$

Table 3. Square root of mean square error of average length (SMSE) between markers and mean lod score (MLS) with different frequencies of marker allele in different interval between markers when the considered number of alleles is two

\begin{tabular}{|c|c|c|c|c|c|c|}
\hline \multicolumn{2}{|c|}{ Gene frequency } & \multirow{3}{*}{$\begin{array}{l}\text { Standard } \\
\text { deviation from } \\
\text { regular interval } \\
\text { (M) }\end{array}$} & \multicolumn{4}{|c|}{ Real interval between markers $(\mathrm{M})$} \\
\hline \multirow{2}{*}{ Sire line } & \multirow{2}{*}{ Dam line } & & \multicolumn{2}{|c|}{0.05} & \multicolumn{2}{|c|}{0.10} \\
\hline & & & SMSE & MLS & SMSE & MLS \\
\hline \multirow[t]{4}{*}{0.3} & 0.7 & 0.00 & 0.023 & 18.64 & 0.034 & 13. 6 \\
\hline & & 0.01 & 0.023 & 18. 69 & 0.034 & 13.62 \\
\hline & & 0.02 & 0.023 & 18.87 & 0.034 & 13. 81 \\
\hline & & 0.03 & 0.023 & 18.89 & 0.034 & 13.81 \\
\hline \multirow[t]{4}{*}{0.4} & 0.6 & 0.00 & 0.025 & 16.55 & 0.037 & 12.23 \\
\hline & & 0.01 & 0.026 & 16.61 & 0.037 & 12.28 \\
\hline & & 0.02 & 0.026 & 16.76 & 0.037 & 12.36 \\
\hline & & 0.03 & 0.026 & 16.66 & 0.038 & 12.20 \\
\hline \multirow[t]{4}{*}{0.5} & 0.5 & 0.00 & 0.025 & 16.02 & 0.039 & 11.52 \\
\hline & & 0.01 & 0.026 & 16.02 & 0.038 & 11.57 \\
\hline & & 0.02 & 0.027 & 16.01 & 0.038 & $11.5 \%$ \\
\hline & & 0.03 & 0.027 & 16.08 & 0.038 & 12.06 \\
\hline \multirow[t]{4}{*}{0.4} & 0.4 & 0.00 & 0.027 & 14.76 & 0.042 & 10.92 \\
\hline & & 0.01 & 0.028 & 14.80 & 0.042 & 10.95 \\
\hline & & 0.02 & 0.028 & 15.04 & 0.041 & 11.05 \\
\hline & & 0.03 & 0.029 & 14.81 & 0.040 & 11.19 \\
\hline \multirow[t]{4}{*}{0.3} & 0.3 & 0.00 & 0.031 & 12.03 & 0.051 & 8.70 \\
\hline & & 0.01 & 0.033 & 11.94 & 0.050 & 8.73 \\
\hline & & 0.02 & 0.034 & 12.05 & 0.050 & 8.85 \\
\hline & & 0.03 & 0.035 & 12.00 & 0.049 & 8.85 \\
\hline
\end{tabular}

マーカー間の距離のばらつきは，連銷解析の効率にほ とんど影響しないことが明らかとなった。 ただし、マー カ一間の距離を無作為に設定した場合には連銷解析の効 率は低くなることが明らかになっている(1)。このように マーカーの間隔が極端にばらついている場合には連鎖解 析の効率に影響すると考えられる。しかし，一般にマー カーはできる限り等間隔に選定される。本研究の結果 は, マーカーの間隔が $5 \pm 3 \mathrm{cM}$ あるいは $10 \pm 3 \mathrm{cM}$ 程度 のばらつきならば，連鎖解析の効率にはほとんよ゙影響し ないことを示している.このことから，隣接したマー カ一が複数存在する場合には，マーカーの選定には多型 数や遺伝子頻度を基準にすればよいと考えられる.

現在，様々な家畜で標集家系が作成され，それに基づ

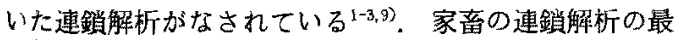
終的な目的の 1つは，遺伝子の位置を同定するとともに それが形質に与える効果の大きさを推定することにあ
る。質的形質に関与する遗伝子やある量的形翼に対して 非常に大きな約果を持つ主働遗伝子が存在する場合は之 むかく，一般に量的形質に関与する遺伝子を同定するた わには多くの個体について形質を测定する必要がある. また，遗伝的特性は種あるいは品種によって異なるた め，様々な品種（媑）の組み合わせを用いて遺伝子を同 定する必要がある，そのためには既存の標準家系だけで は十分之はいえず，今後上り多くの標準家系を作成し， 研究を進めていく必要があると考えられる.

これまでの標準家系の作成に関する一連の研究結 果 ${ }^{10-12)}$ により, 連敛不平衡の程度， $F_{1}$ 世代の交配方法, 標準家系の大きさおよびマーカーの間隔が連鎖解析の効 率に及ぼす影響を明らかにした，一方本研究では，標準 家系を用いた連鎖解析において，マーカーの多型数なら びにその頻度, マーカー間の距離のばらつきの程度など の影響を明らかにした，これらの研究結果は，標準家系 


$$
\text { 佐藤 - 古川 }
$$

Table 4. Square root of mean square error of average length (SMSE) between markers and mean lod score (MLS) with different number of alleles in different interval between markers when the considered frequency of marker allele is reciprocal number of alleles

\begin{tabular}{|c|c|c|c|c|c|c|}
\hline \multicolumn{2}{|c|}{ Number of alleles } & \multirow{3}{*}{$\begin{array}{l}\text { Standard } \\
\text { deviation from } \\
\text { regular interval } \\
\text { (M) }\end{array}$} & \multicolumn{4}{|c|}{ Real interval between markers (M) } \\
\hline \multirow{2}{*}{ Sire line } & \multirow{2}{*}{ Dam line } & & \multicolumn{2}{|c|}{0.05} & \multicolumn{2}{|c|}{0.10} \\
\hline & & & SMSE & MLS & SMSE & MLS \\
\hline \multirow[t]{4}{*}{2} & 2 & 0.00 & 0.025 & 15.87 & 0.038 & 11.72 \\
\hline & & 0.01 & 0.026 & 16.08 & 0.038 & 11.75 \\
\hline & & 0.02 & 0.027 & 16.05 & 0.038 & 11.82 \\
\hline & & 0.03 & 0.026 & 15.99 & 0.037 & 11.97 \\
\hline \multirow[t]{4}{*}{2} & 3 & 0.00 & 0.018 & 30.25 & 0.026 & 22.28 \\
\hline & & 0.01 & 0.019 & 30.51 & 0.026 & 22.35 \\
\hline & & 0.02 & 0.019 & 30.56 & 0.026 & 22. 46 \\
\hline & & 0.03 & 0.019 & 30.50 & 0.026 & 22.62 \\
\hline \multirow[t]{4}{*}{2} & 4 & 0,00 & 0.016 & 39.63 & 0.023 & 29.29 \\
\hline & & 0.01 & 0.016 & 39.95 & 0.023 & 29. 38 \\
\hline & & 0.02 & 0.016 & 40.10 & 0.023 & 29.54 \\
\hline & & 0.03 & 0.016 & 40.03 & 0.023 & 29.81 \\
\hline \multirow[t]{4}{*}{3} & 3 & 0.00 & 0.018 & 31.36 & $0.025=$ & 23. 13 \\
\hline & & 0.01 & 0.018 & 31.54 & 0.025 & 23. 19 \\
\hline & & 0.02 & 0.018 & 31.90 & 0.025 & 23. 29 \\
\hline & & 0.03 & 0.018 & 31.82 & 0.025 & 23. 56 \\
\hline \multirow[t]{4}{*}{3} & 4 & 0.00 & 0.016 & 41.62 & 0.022 & 30. 14 \\
\hline & & 0.01 & 0.016 & 40.89 & 0.022 & 30.22 \\
\hline & & 0.02 & 0.016 & 41. 37 & 0.022 & 30.40 \\
\hline & & 0.03 & 0.016 & 41.08 & 0.022 & 30.50 \\
\hline \multirow[t]{4}{*}{4} & 4 & 0.00 & 0.016 & 41.40 & 0.022 & 30.53 \\
\hline & & 0.01 & 0.016 & 41. 58 & 0.022 & 30.16 \\
\hline & & 0.02 & 0.016 & 42.01 & 0.022 & 30.88 \\
\hline & & 0.03 & 0.016 & 41.76 & 0.021 & 30.98 \\
\hline
\end{tabular}

を用いて効率的に連鎖解析を行うたかの1つの指標にな゙ りえると考える。

\section{女献}

1) Archibald AL, Haley CS, Anderson L, Bosma AA, Dacies W, Fredholm M,Geldermann $\mathrm{H}$, Gellin J, Groenen M, Gustavsson I, Ollivier L, Tucker EM, Van de Weghe A. PiGMaP : An European initiative to map the porcine genome. Anim. Genet., 22 : (suppl, 1) 82-83. 1991.

2) Archibald AL, Haley CS, Brown JF, Couperwhite S, McQueen HA, Nicholson, D, Coppieters W, Van de Weghe A, Stratil A,
Winterø AK, Fredholm M, Larsen NJ, Nielsen VH, Milan D, Woloszyn N, Robic A, Dalens M Riquet J, Gellin J, Caritez JC, Burgaud G, Ollivier L, Bidanel JP, Vaiman M, Renard C, Geldermann H, Davoli R, Ruyter D, Verstege EJM, Groenen MAM, Davies W, Høy heim B, Keiserud A, Andersson L, Ellegren $\mathrm{H}$, Johansson M, Marklund L, Miller JR, Anderson Dear DV, Signer E, Jeffreys AJ, Moran C, Le Tissier P, Muladno, Rothschild MF, Tuggle CK, Vaske D, Helm J, Liu HC, Rahman A, Yu TP, Larson RG, Schmitz CB. The PiGMaP consortium linkage map of the pig (Sus scrofa). Mamm. Genome, 6 : 157-175: 1995. 
3) Bishop MD, Kappes SM, Keele JW, Stone RT, Sunden SLF, Hawkins GA, Toldo SS, Fries R, Grosz MD. Yoo J, Beattie CW. A genetic linkage map for cattle. Genetics, 136 : 619-639. 1994.

4) Botstein D, White RL, Skolnick M, Davis W. Construction of a genetic linkage map in man using restriction fragment length polymorphisms. Am. J. Hum. Genet., 32 : 314-331. 1980.

5) Elsen JM, Mangin B, Goffinet B, Chevalet C. Optimal structure of protocol designs for building genetic linkage maps in livestock. Theor. Appl. Genet., 88 : 129-134. 1994.

6) Geldermann H. Mapping quantitative traits by means of genetic markers. Proc. 4th World Congr. Genet. Appl. Livestock Prod., 13 :97106. 1990 .

7) Morton NE. Sequential tests for the detection of linkage. Am. J, Hum. Genet., $7: 277-318$. 1955.

8) Ott J. Analysis of human genetic linkage. 1st ed. 54-107. The Johns Hopkins Univ. Press. London. 1991.
9) Rohrer GA, Alexander LJ, Keele JW, Smith TP. A microsatellite linkage map of the porcine genome. Genetics, $136: 231-245.1994$.

10）佐藤正宽・古川力. 連鎖不平衡が連鎖解析の効 率に及ぼす影響，日畜会報，68:956-964， 1997.

11）佐藤正覞·古川力。二重相互交配に上る標準家 䒺の $F_{1}$ 世代の交配方法が連銷解析の效率に及ば す影響. 日畜会報， $69: 26-31.1998$.

12）伀藤正筧・古川力。二重相互交配に上る櫒準策 系の大きさおよび染色体上のマーカーの間隔少連 銷解析の効率に及ぼす影響。日畜会報，69：4652. 1998.

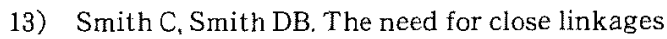
in marker-assisted selection for economic merit in livestock. Anim. Breed. Abst., 61 : 197204. 1994.

14) Van der Beek S, van Arendonk JAM. Criteria to optimize designs for detection and estimation of linkage between marker loci from segregating populations containing several families. Theor. Appl. Genet., 86 : 269-280. 1993. 
佐藤・古川

\title{
Effects of Mating Types of Reference Family and Degree of Polymorphism on Constructing Genetic Linkage Map
}

\author{
Masahiro SATOH and Tsutomu FURUKAWA \\ National Institute of Animal Industry, Tsukuba Norin \\ Kenkyu Danchi, Ibaraki-ken 305-0901
}

\begin{abstract}
Effects of mating types of reference family, and number of marker alleles and the frequency were investigated using Monte Carlo computer simulation. The genetic linkage map was constructed using a reference population of intercross $\left(F_{2}\right)$ or backcross comprising of 24 full sib families and 192 progenies derived from a cross between 12 sires and 24 dams. $F_{1}$ animals were produced by crossing three grandsires from a different breed with six grandams from another breed. Five types of reference populations were used to investigate the effect of mating types: $F_{2}$, four types of backcross between $F_{1}$ sires and purebred dams in male or female line, and between $F_{1}$ dams and purebred sires in male or female line. Each dam produced eight progenies. A chromosomal map length of $1.2 \mathrm{M}$ (Morgans), different number of alleles and their frequencies were assumed. The considered average intervals between markers were $0.05,0.10,0.15$ or $0.20 \mathrm{M}$ with standard deviation of $0.0,0.01,0.02$ or $0.03 \mathrm{M}$, respectively. The distance between markers and lod scores were estimated using genoty pic data from a reference population. $F_{2}$ had a higher lod score than backcross, hence $F_{2}$ was preferred to backcross in the construction of linkage map. Efficiency of linkage analysis in the $F_{2}$ increased consistently, but the rate declined steadily as the number of alleles increased. The efficiency of linkage analysis did not depend on marker spacing.
\end{abstract}

Anim. Sci. Technol. (Jpn.) 69 (5) : 460-468, 1998

Key words : Linkage analysis, Degree of polymorphism, Marker loci, Computer simulation 